\title{
Нейротрофическое обеспечение коры головного мозга при болезни Альцгеймера: транскриптомный анализ
}

Козлова Т.А.*, Рудницкая Е.А., Стефанова Н.А., Колосова Н.Г.

Институт цитологии и генетики СО РАН, Новосибирск, Россия

*e-mail: Kozlovatanya21@gmail.com

Ключевые слова: болезнь Альцгеймера, нейротрофические факторы, RNA-Seq, крысы OXYS

Мотивация и цель: болезнь Альцгеймера (БА) - наиболее распространенная форма сенильной деменции. Изменение с возрастом нейротрофического обеспечения головного мозга может вносить вклад в развитие БА, однако механизмы, лежащие в его основе, изучены недостаточно из-за невозможности исследовать эти процессы в динамике у людей, а также отсутствия адекватных биологических моделей. Уникальной моделью БА является линия крыс OXYS. Цель работы исследование динамики изменения сигнального пути нейротрофинов в коре головного мозга крыс OXYS при развитии признаков БА и в post mortem образцах коры головного мозга пациентов с БА. Материальы и методы: массовое параллельное секвенирование (RNA-Seq) префронтальной коры крыс OXYS и Вистар (контроль) проводили в ЗАО «Геноаналитика» (г. Москва). Данные RNA-seq префронтальной коры пациентов с БА и когнитивно здоровых людей получали из базы данных DDBJ Sequence Read Archive, \#SRA060572. Анализ изменения экспрессии генов сигнального пути нейротрофинов проводили, используя базы данных KEGG и DAVID.

Peзультаты: анализ транскриптома префронтальной коры головного мозга крыс OXYS и Вистар показал, что в период манифестации признаков БА у крыс OXYS (с 20 дней до 5 мес.) имеют место сходные изменения экспрессии генов сигнального пути нейротрофинов в коре головного мозга крыс обеих линий: уровень мРНК 45 генов изменялся однонаправленно. В период усиленной прогрессии признаков БА (с 5 до 18 мес.) количество дифференциально экспрессирующихся генов сигнального пути нейротрофинов у крыс OXYS было на порядок больше, чем у крыс Вистар. Важно отметить, что с возраста 20 дней до 18 мес. в коре головного мозга крыс OXYS однонаправленными были изменения экспрессии только 3 генов, а экспрессия 30 генов изменялась разнонаправлено. Анализ данных транскриптома префронтальной коры пациентов с БА и когнитивно здоровых людей показал, что у пациентов с БА изменен уровень мРНК 20 генов сигнального пути нейротрофинов, 15 из которых имели сниженную экспрессию, связанную с негативной регуляцией актинового цитоскелета и роста аксонов, ареста клеточного цикла и дифференцировки клеток, нейрональной пластичности. Повышенный уровень мРНК 5 генов сигнального пути нейротрофинов ассоциирован с дисрегуляцией ретроградного транспорта, а также выживаемости клеток и их гибели.

Заключение: таким образом, развитие признаков БА сопровождается дисрегуляцией сигнального пути нейротрофинов в перфронтальной коре головного мозга. Результатом этой дисрегуляции может стать подавление сигнального пути нейротрофинов, наблюдаемое у пациентов с БА. Благодарности: работа поддержана грантом РНФ № 19-15-00044. 